\title{
PEMANFAATAN VIDEO YOUTUBE TENTANG ANEMIA PADA REMAJA PUTRI DI SMK YP SEI PALANGKA RAYA
}

\section{Utilization Of Youtube Video About Anemia On Adolescent Girls In Smk Yp Sei Palangka Raya}

\author{
Erina Eka Hatini ${ }^{*}$ \\ Noordiati $^{2 *}$
}

*IPoltekkes Kemenkes Palangka Raya, Palangka Raya, Kalimantan Tengah, Indonesia

2Poltekkes Kemenkes Palangka Raya, Palangka Raya,

Kalimantan Tengah, Indonesia

*email:

erinaeka@poltekkes-

palangkaraya.ac.id

\begin{abstract}
Abstrak
Latar Belakang: Angka prevalensinya anemia sekitar 29\% (496 juta) terjadi pada wanita yang tidak hamil, dan sekitar $38 \%$ atau 32,4 juta wanita hamil usia 15-49 tahun mengalami anemia. (WHO, 20l4). Sekitar $23 \%$ remaja perempuan mengalami anemia akibat kekurangan zat besi serta memiliki pengetahuan yang rendah tentang anemia. Tujuan Penelitian: Menganalisis pemanfaatan Video Youtube terhadap peningkatan pengetahuan remaja putri tentang Anemia.

Metodologi Penelitian: Penelitian dengan rancangan one group comparison pretestposttest design.

Hasil : Sekitar $96 \%$ responden berumur 14 - 16 tahun, $4 \%$ responden berumur $\geq 17$ tahun. Sebanyak 100\% remaja Putri mengetahui informasi tentang Anemia dari penyuluhan kesehatan oleh tenaga kesehatan. Sekitar 64\% remaja Putri mengalami haid sekitar umur 10-13 tahun, sekitar 36\% pada umur 14-16 tahun. Analisis dengan menggunakan uji Wilcoxon, skor rata-rata pengetahuan remaja adalah 52.00 sebelum intervensi dan setelah intervensi rata-rata skor pengetahuan remaja sekitar 83.60.

Kesimpulan: Hasil analisis didapatkan $p$-value sebesar $0.000 \quad(p<0.05)$ yang menunjukkan intervensi penyuluhan video meningkatkan pengetahun remaja tentang anemia secara signifikan
\end{abstract}

Kata Kunci:

Anemia

Remaja Putri

Video Youtube

Keywords:

Anemia

Young girls

Youtube Video

\begin{abstract}
Background: Prevalence of anemia is about 29\% (496 million) in women who are not pregnant, and about $38 \%$ or 32.4 million pregnant women aged 15-49 years are anemic. (WHO, 20l4). About 23\% of adolescent girls experience anemia due to iron deficiency and have low knowledge about anemia.

Objective: This study aims to Analyzing the use of Video Youtube to increase knowledge of young girls about Anemia.

Research Methodology: This study was using one design group comparison pretestposttest design .

Results: About $96 \%$ of respondents are $14-16$ years old, $4 \%$ of respondents are $\geq 17$ years old. As many as $100 \%$ of young girls know information about anemia from health education by health workers. Around $64 \%$ of young girls experience menstruation around the age of $10-13$ years, $36 \%$ at age $14-16$ years. Analysis using the Wilcoxon test , the average score of girls knowledge was 52.00 before the intervention and after the intervention the average knowledge score of the young girls was around 83.60.

Conclusion: the analysis was obtained $p$-value of $0.000(p<0.05)$, which indicates the intervention counseling video increase young girlst knowledge about anemia significantly.
\end{abstract}

(c) year The Authors. Published by Institute for Research and Community Services Universitas Muhammadiyah Palangkaraya. This is Open Access article under the CC-BY-SA License (http://creativecommons.org/licenses/by-sa/4.0/). DOI: https://doi.org// $0.33084 /$ jsm.vxix.xxx.

\section{PENDAHULUAN}

Anemia adalah suatu kondisi dimana jumlah dan ukuran sel darah merah atau kadar haemoglobin lebih rendah dari standar yang mengakibatkan terganggunya kapasitas darah yang mengangkut oksigen ke seluruh tubuh.
Anemia merupakan salah satu indikator gizi yang buruk dan kesehatan yang buruk. Anemia adalah salah satu masalah kesehatan yang angka prevalensinya masih tinggi di dunia yaitu sekitar 29\% (496 juta) terjadi pada wanita yang tidak hamil, dan sekitar $38 \%$ atau 32,4 juta wanita hamil usia 15-49 tahun mengalami anemia. 
(WHO, 20I4) Salah satu masalah yang dihadapi remaja Indonesia adalah masalah gizi mikronutrien, yakni sekitar $12 \%$ remaja laki-laki dan $23 \%$ remaja perempuan mengalami anemia, yang sebagian besar diakibatkan kekurangan zat besi (anemia defisiensi besi).(Kemenkes, 2018).

Data Riskesdas bahwa tahun 2013 wanita yang mengalami anemia sekitar 37,1\% dan kemudian data tahun 2018 menunjukkan hasil bahwa wanita yang mengalami anemia mengalami peningkatan yaitu sebesar $48,9 \%$. Wanita yang mengalami anemia pada tahun 2018 sekitar 84,6\% berusia 15 -24 tahun. Proporsi remaja yang mendapatkan Tablet Tambah Darah (TTD) sekitar $76,2 \%$, yang mendapatkan TTD di sekolah sekitar $80,9 \%$ namun yang mengkonsumsi TTD $\geq 52$ butir hanya sekitar 1,4 . Sedangkan ibu hamil yang mendapat TTD sekitar 73,2 dan hanya 24 yang mendapat $\geq 90$ butir, dan sekitar 38,I $\geq 90$ butir. (Litbangkes Kemenkes, 2018).

Anemia dan kekurangan zat besi mengakibatkan berkurangnya kondisi kesejahteraan seseorang, karena mudah lelah, lesu dan mengurangi kekuatan fisik dan kinerja. Anemia pada seorang ibu bisa mengakibatkan kesakitan dan kematian baik pada ibu dan janin antara lain risiko keguguran, lahir mati, premature, dan berat badan lahir rendah. (WHO, 20I4). Penyebab paling umum anemia pada seorang wanita adalah kekurangan zat besi, yang disebabkan penyerapan atau asupan zat besi yang kurang memadai, peningkatan kebutuhan zat besi pada masa pertumbuhan atau kehamilan, kehilangan zat besi pada saat menstruasi ataupun infeksi cacingan. (WHO, 2014).

Remaja adalah masa transisi dari masa kanak-kanak ke masa remaja. Remaja adalah penduduk dalam rentang usia 10 - 18 tahun dan belum menikah. Masa remaja merupakan periode terjadinya pertumbuhan dan perkembangan yang pesat baik secara fisik, psikologis maupun intelektual. (Pusdatin Kemenkes RI, 20I4) Pubertas adalah masa transisi dari masa anak ke masa dewasa, ditandai dengan munculnya tanda-tanda seksual sekunder dan kemampuan bereproduksi. Perubahan fisik pubertas dimulai sekitar usia 10 atau II tahun pada remaja putri dan akan mengalami menarche (Indaryani, W., dkk , 20l0).

Menurut WHO dalam Pusdatin Kemenkes RI, 2014 bahwa di dunia diperkirakan jumlah remaja adalah sekitar 1,2 milyar atau 18\% dari jumlah penduduk. Pada Kesehatan Reproduksi Remaja (KRR) sebagai bagian dari kegiatan Survei Demografi dan Kesehatan Indonesia (SDKI) 2012 dari 19.399 responden dewasa muda ada sekitar 8.419 orang $(66 \%)$ remaja berumur 15-19 tahun. Sekitar 23\% Remaja wanita mendapatkan haid pertama kali saat mereka berumur 12 tahun, sekitar 29\% pada umur I3 tahun , $24 \%$ pada umur 14 tahun, ada fenomena yang menarik sekitar $7 \%$ wanita mengalami haid pertamanya pada usia 10 - II tahun. Sekitar 53\% remaja wanita membahas mengenai haid dengan teman dan sekitar 4l\% dengan ibunya. (BPS, BKKBN, Kemenkes dan ICF International, 20I3).

Pada wanita terjadi kehilangan darah setiap bulannya melalui menstruasi. Jika darah yang keluar sangat banyak maka akan terjadi defisiensi zat besi. Prevalensi anemia pada remaja masih sangat tinggi jika tidak tertangani dengan baik akan berlanjut sampai usia dewasa, Anemia pada remaja berdampak buruk terhadap penurunan imunitas, kosentrasi, prestasi belajar, kebugaran remaja dan produktifitas. Selain itu, secara khusus anemia yang dialami remaja putri akan berdampak lebih serius mengingat mereka merupakan calon ibu yang akan hamil dan melahirkan bayi, memperbesar risiko kematian ibu melahirkan, bayi lahir prematur dan berat badan lahir rendah (BBLR) (Kemenkes , 2018).

Survei Demografi dan Kesehatan Reproduksi Remaja tahun 2012 menunjukkan masih rendahnya tingkat pengetahuan remaja (15-24 tahun) terkait anemia, sebanyak $67 \%$ responden wanita menyebutkan penyebab anemia dengan kategori lainnya dan tidak tahu sama sekali (SDKI, 20I2). Menurut data Riskesdas 2013 menunjukkan semakin tinggi pendidikan terkait pengetahuan, maka semakin besar persentase cakupan 
konsumsi zat besi (Riskesdas, 2013). Menurut Data dan Informasi Profil Kesehatan Indonesia 2016 persentase remaja putri yang mendapat tablet tambah darah (TTD) untuk Propinsi Kalimantan Tengah hanya sekitar 12,4\% dan tahun 2017 sekitar 12,93\%. Rendahnya pengetahuan tentang anemia akan berdampak pada risiko pengalaman kesehatan reproduksi mereka kelak. Risiko anemia pada remaja lebih tinggi terjadi pada waktu seorang wanita hamil . Kesadaran pemahaman tentang anemia sangat penting.

Penelitian tentang hubungan pengetahuan remaja putri tentang anemia dengan perilaku pencegahan anemia pada saat menstruasi di SMK Nusa Bhakti Kota Semarang yang dilakukan oleh Mularsih (2017) menyimpulkan bahwa perlunya peningkatan pengetahuan remaja putri tentang anemia untuk pencegahan anemia saat menstruasi. Pendidikan kesehatan merupakan salah satu metode yang tepat untuk memberikan informasi kepada remaja. Hasil SDKI 2012 menyarankan agar pengelola program kesehatan reproduksi remaja yang terkait mengembangkan materimateri dan informasi kepada remaja tentang masalah anemia. (SDKI, 20I2).

Penelitian Wahyuni, et al (20I5) bahwa penggunaan media audio visual lebih efektif dibandingkan dengan kelas klasikal, dimana kelompok intervensi diberikan dengan media audio visual menggunakan macromedia flash, kemudian pada kelompok control hanya berisi paparan materi. Hasil penelitian menunjukkan nilai posttest kelas intervensi $86,95 \%$ di atas nilai KKM dan pada kelas kontrol nilai posttest sekitar 78,26\%. Media audio visual dalam pembelajaran bisa membuat pelajaran lebih menarik terarah sedangkan kelas yang disampaikan hanya dengan paparan siswa merasa lebih cepat bosan dan jenuh.

Berdasarkan tersebut di atas maka peneliti bermaksud untuk memberikan kontribusi berupa pengembangan media Video untuk meningkatkan pengetahuan pada remaja putri tentang anemia di Kota Palangka Raya.

\section{METODOLOGI}

Jenis penelitian ini adalah penelitian Quasi Eksperimen, dengan rancangan one group comparison pretest-posttest design. Penelitian dilakukan di SMK ISEI Palangka Raya di JI. Yos Sudarso Palangka Raya. remaja putri yang memiliki berusia 14-18 tahun yang bersekolah di SMK YP ISEl Palangka Raya. Pada penelitian ini, penentuan sampel ditentukan secara Nonprobability Sampling metode sampling aksidental.

Pengumpulan data pada penelitian ini menggunakan data primer yang diperoleh dari pengisian kuesioner oleh responden.

Analisis data yang digunakan meliputi analisis univariat untuk melihat karakteristik Subjek Penelitian menggunakan distribusi frekuensi dan persentase. Analisis bivariat dilakukan untuk mengidentifikasi hubungan anatar dua variable, yaitu untuk menganalisis skor pengetahuan prepost dan posttest dengan tingkat kemaknaan $p<0.05$.

\section{HASIL DAN PEMBAHASAN}

HASIL

Hasil penelitian yang telah diperoleh tentang perbedaan pengetahuan Pretest dan Posttest tentang anemia pada remaja putri didapatkan bahwa dari 25 sampel penelitian, sebanyak 24 (96\%) remaja Putri berumur 14 - 16 tahun, I orang (4\%) berumur $\geq 17$ tahun. Secara deskriptif ditunjukkan bahwa mayoritas sampel penelitian berumur antara 14-16 tahun. 


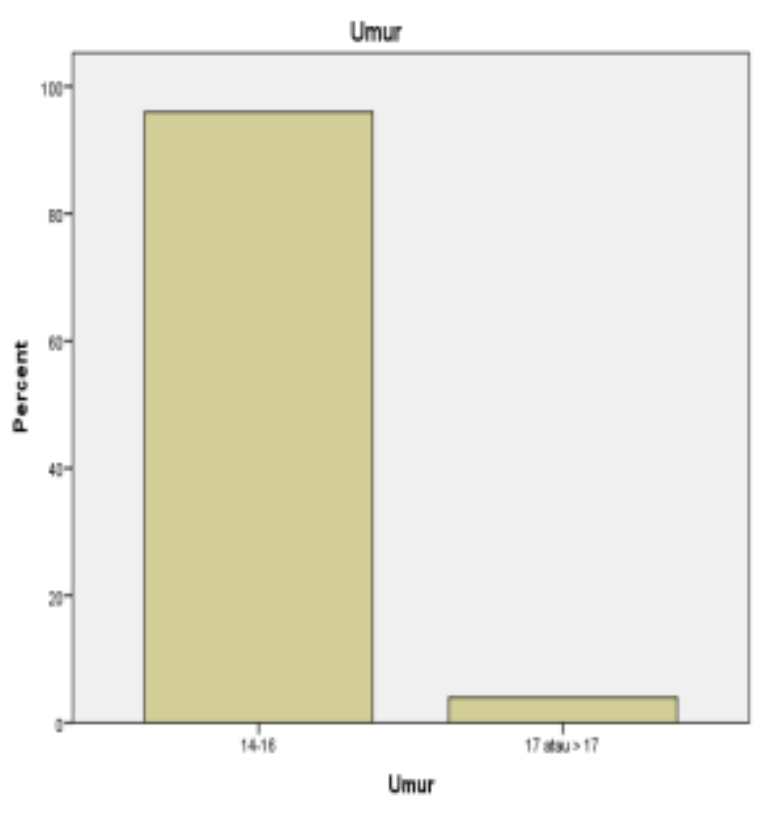

\section{Gambar I. Karakteristik Umur Remaja Putri}

Sebanyak 25 orang (100\%) remaja Putri mengetahui informasi tentang Anemia berasal dari informasi yang didapatkan dari penyuluhan kesehatan oleh tenaga kesehatan.

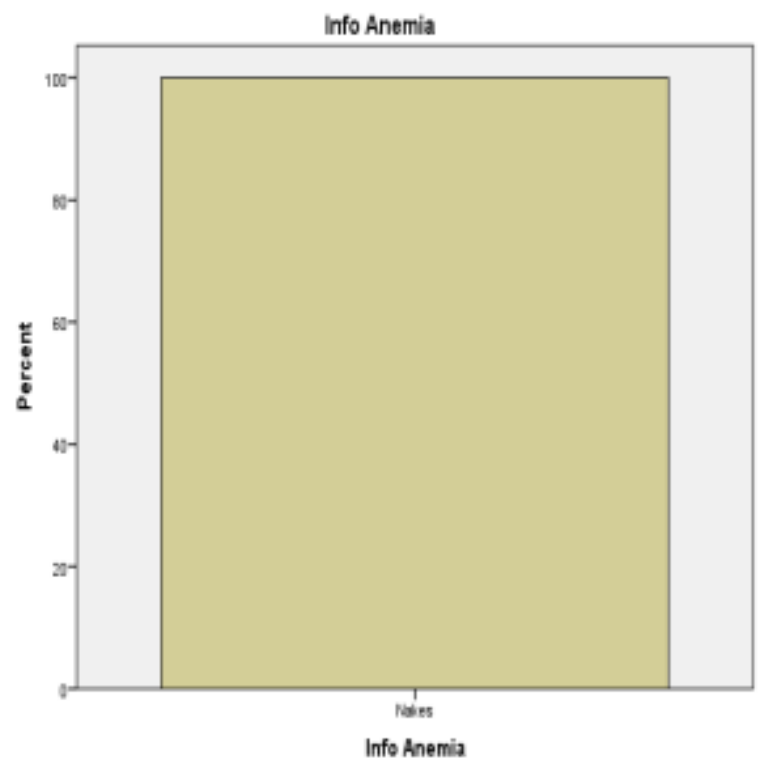

Gambar 2. Sumber Informasi mengenai Anemia

Semua responden sudah mendapatkan haid, sebanyak 16 orang (64\%) remaja Putri mengalami haid pada usia remaja awal umur yaitu sekitar umur 10-13 tahun, sebanyak 9 orang (36\%) remaja Putri mengalami haid pada usia remaja pertengahan yaitu sekitar umur 14-16 tahun. Secara deskriptif ditunjukkan bahwa paling banyak sampel penelitian mulai mengalami haid diantara umur 10-13 tahun.

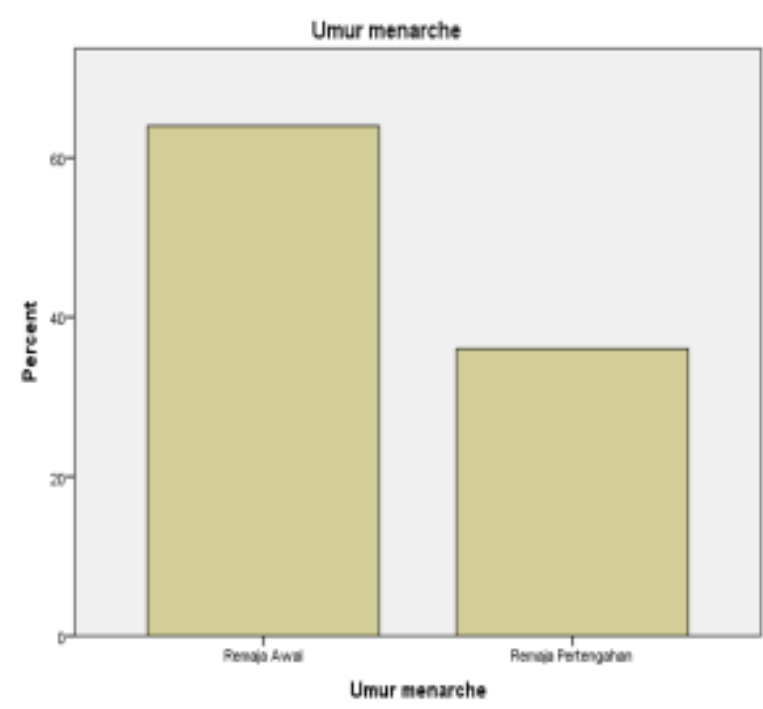

\section{Gambar 3. Karakteristik Umur Menarche Remaja Putri}

Sebelum dilakukan analisis data lebih lanjut, terlebih dahulu dilakukan uji asumsi normalitas pada data untuk menentukan metode analisis selanjutnya yang akan digunakan. Jika normalitas data terpenuhi, maka proses perbandingan pengetahuan saat sebelum dengan sesudah intervensi dilakukan dengan uji t berpasangan. Namun, jika asumsi normalitas tidak terpenuhi, maka proses perbandingan pengetahuan saat sebelum dengan sesudah intervensi dilakukan dengan uji Wilcoxon. Proses uji normalitas data dilakukan dengan menggunakan metode deskriptif dengan parameter histogram. Berikut hasil uji normalitas data :

Tabel I. P-Value Uji Normalitas Data Menggunakan Uji Shapiro-Wilk

\begin{tabular}{cc}
\hline Variabel & P Value \\
\hline Pengetahuan Pre & 0.027 \\
Pengetahuan Post & 0.014 \\
\hline
\end{tabular}

Berdasarkan pada tabel di atas, pada variabel pengetahuan pada saat sebelum dan sesudah intervensi didapatkan $p$-value kurang dari 0.05 ( $p<0.05)$. P-value kurang dari 0.05 menunjukkan bahwa normalitas data 
pada variabel pengetahuan tidak berdistribusi normal. Oleh karena itu pengujian hipotesis pada variabel pengetahuan dilakukan dengan pendekatan statistika nonparametrik yakni dengan menggunakan uji Wilcoxon.

Skor pengetahuan sebelum dengan sesudah intervensi dengan pemberian penyuluhan tentang anemia dengan media video youtube dilakukan dengan menggunakan uji Wilcoxon. Berikut hasil pengujian perbandingan pengetahuan sebelum dengan sesudah intervensi dengan Video :

Tabel 2. Hasil Analisis Uji Wilcoxon Perbandingan Pengetahuan Pretest dan Posttest

\begin{tabular}{|c|c|c|c|c|}
\hline Variabel & $n$ & $\begin{array}{l}\text { Median } \\
\text { (min- } \\
\text { maks) }\end{array}$ & $\begin{array}{c}\text { Rerata } \pm \\
\text { s.b. }\end{array}$ & $p$ \\
\hline $\begin{array}{l}\text { Pengetahuan } \\
\text { Pretest }\end{array}$ & 25 & $\begin{array}{c}50(30- \\
75)\end{array}$ & $\begin{array}{c}52.00 \pm \\
9.24\end{array}$ & 0,000 \\
\hline $\begin{array}{l}\text { Pengetahuan } \\
\text { Posttest }\end{array}$ & 25 & $\begin{array}{c}85(70- \\
95)\end{array}$ & $\begin{array}{c}83.60 \pm \\
5.11\end{array}$ & \\
\hline
\end{tabular}

Berdasarkan pada Tabel 5, pada saat sebelum diberikan intervensi media video, skor rata-rata pengetahuan remaja adalah sebesar $52.00 \pm 9.24$. Setelah diberikan intervensi, pengetahuan remaja meningkat menjadi rata-rata $83.60 \pm 5.1 \mathrm{l}$. Secara statistik, dengan menggunakan uji Wilcoxon didapatkan $\mathrm{p}$-value sebesar $0.000 \quad(\mathrm{p}<0.05)$ yang menunjukkan adanya perbedaan yang signifikan rata-rata skor pengetahuan remaja Putri antara sebelum dengan sesudah intervensi. Dari pengujian ini secara empirik telah terbukti bahwa memberikan penyuluhan video mampu meningkatkan pengetahun remaja tentang anemia secara signifikan.

\section{PEMBAHASAN}

Hasil uji homogenitas responden berdasarkan usia, sumber informasi tentang anemia dan usia menarche menunjukkan bahwa sampel berada pada posisi yang setara, sehingga jika terdapat peningkatan pengetahuan setelah mendapatkan intervensi maka mencerminkan bahwa peningkatan pengetahuan yang terjadi karena intervensi yang diberikan.

Hasil penelitian menunjukkan terdapat perbedaan secara signifikan skor pengetahuan pre dan post test. Adanya perbedaan pengetahuan dari pre dan post test masing-masing kelompok menunjukkan bahwa media penyampaian informasi video youtube tentang anemia pada remaja putri dapat meningkatkan pengetahuan.

Pendidikan kesehatan dapat dilakukan dengan berbagai media, salah satunya adalah media audiovisual. Menurut Juliantara (2009) media audivisual adalah alat bantu mengajar yang mempunyai bentuk gambar dan mengeluarkan suara. Media audiovisual menampilkan unsur gambar dan suara secara bersamaan pada saat mengkonsumsi pesan atau informasi. Kelebihan menggunakan media audiovisual adalah memberikan gambaran yang lebih nyata serta meningkatkan retensi memori karena lebih menarik dan mudah diingat (Sadiman, 2009). Pencarian informasi tentang perilaku seksual remaja saat ini didukung oleh perkembangan dan kemajuan teknologi informasi berupa internet yang sedang diminati dan digemari oelh remaja. Internet meliputi gadget dan smartphone yang banyak digunakan remaja dalam interaksi sosial mereka. (Suyatno, 20I I) Perkembangan teknologi pendidikan tidak dapat dilepaskan dengan perkembangan teknologi pada umumnya. Berbagai perangkat pendidikan dan saran pendidikan yang modern turut mendukung optimalisasi proses pembelajaran, baik di tingkat sekolah maupun dalam kehidupan sehari-hari. (Haryoko, 2009)

Perubahan perilaku di dalam proses pendidikan orang dewasa (andragogi) pada umumnya lebih sulit daripada perubahan perilaku di dalam pendidikan anak (pedagogi), karena orang dewasa sudah mempunyai pengetahuan, sikap dan keterampilan yang sudah dimiliki sebelumnya, sehingga media serta metode pembelajaran yang merupakan salah satu komponen dalam proses belajar memegang peranan yang sangat penting, karena 
kedua aspek ini saling berkaitan. Pemilihan salah satu metode mengajar tertentu akan mempengaruhi jenis media pembelajaran yang sesuai, meskipun masih ada komponen lain yang harus diperhatikan dalam memilih media pembelajaran (Notoatmodjo, 2003).

Hasil uji statistik menunjukkan bahwa terjadi peningkatan pengetahuan pada remaja putri yang mendapatkan pendidikan kesehatan anemia menggunaakan video youtube. Skor pengetahuan remaja putri lebih tinggi setelah diberikan intervensi menggunakan video youtube mengenai anemia sehingga media audiovisual berbasis video youtube dianggap efektif dalam peningkatan pengetahuan remaja putri mengenai anemia.

Hasil penelitian ini sejalan dengan penelitian yang dilakukan oleh Yusuf (2014) menjelaskan bahwa pendidikan kesehatan menggunakan media audiovisual dapat meningkatkan pengetahuan dan sikap ibu dengan anak riwayat kejang demam dengan $\mathrm{p}$ value pengetahuan 0,00 I dan sikap $0,012<\alpha(0,05)$. Hasil penelitian ini juga sejalan dengan penelitian Dar (2014) yang menyatakan bahwa pendidikan kesehatan menggunakan media audiovisual efektif terhadap pengetahuan pelaksanaan senam kaki pada pasien DM tipe 2. Penelitian lain yang dilakukan Jusmiati (2012) menyatakan bahwa pendidikan kesehatan tentang merawat bayi baru lahir dengan menggunakan media audiovisual efektif terhadap peningkatan pengetahuan dan kemampuan merawat bayi baru lahir dengan $p$ value $(0,000)<\alpha(0,05)$.

Penelitian Santi (2014) menyatakan bahwa pendidikan kesehatan dengan media audiovisual efektif terhadap peningkatan pengetahuan, sikap dan perilaku pencegahan filiariasis dengan $p$ value $(0,000)<\alpha(0,05)$. Menurut Arsyad (20II), berpendapat bahwa belajar dengan menggunakan indra ganda (audio dan visual) yaitu indera penglihatan dan pendengaran akan memberikan keuntungan karena siswa siswi akan lebih banyak belajar daripada jika materi pelajaran disajikan stimulasi pandang saja atau dengan saja.
Dalam penelitian ini pemanfaatan media audiavisual dengan media video youtube, dimana perkembangan teknologi pendidikan tidak dapat dilepaskan dengan perkembangan teknologi pada umumnya. Berbagai perangkat pendidikan dan sarana pendidikan yang modern turut mendukung optimalisasi proses pembelajaran, baik di tingkat sekolah maupun dalam kehidupan sehari-hari. Pembelajaran pada hakikatnya adalah proses komunikasi yang bertujuan untuk penyampaian pesan/informasi sehingga dapat merangsang pikiran, perasaan dan minat serta perhatian peserta didik. (Haryoko, 2009)

Menurut Haryoko (2009) dalam proses pembelajaran, pengembangan materi/ bahan ajar dapat melalui berbagai cara, salah satunya adalah pengembangan bahan ajar dengan optimalisasi media. Salah satu media yang digunakan dalam pembelajaran, dan diyakini dapat lebih menggairahkan animo mahasiswa dalam perkuliahan adalah media Audiovisual. Media Audiovisual merupakan salah satu alternative dalam melakukan proses pembelajaran berbasis teknologi.

Hasil Penelitian Raya dan Sukmayati (2016) menunjukkan hasil bahwa remaja yang kurang mendukung kesehatan reproduksi berisiko 2,59 kali untuk melakukan perilaku seksual berisiko dibandingkan remaja yang mendukung kesehatan reproduksi. Puspitaningrum, dkk (2017) menyatakan media juga merupakan salah satu faktor yang mempengaruhi sikap seseorang. Media bermanfaat menimbulkan minat, merangsang untuk meneruskan pesan kepada orang lain dan memudahkan penyampaian informasi. Peningkatan sikap juga dikarenakan peningkatkan pengetahuan . Peningkatan pengetahuan dan sikap ini diperoleh dari proses belajar dengan memanfaatkan semua alat indera, dimana 13\% dari pengetahuan diperoleh melalui indera dengar dan 35-55\% melalui indera pendengaran dan penglihatan.

Media pembelajaran yang dikembangkan berupa aplikasi mobile yang dapat dijalankan pada perangkat bergerak berbasis aplikasi online, sehingga media pembelajaran 
yang dikembangkan dapat dijalankan kapanpun dan dimanapun. Media website banyak digunakan oleh remaja sejak internet menjangkau rumah dan sekolah, sehingga waktu yang dipergunakan remaja untuk mengakses internet pun semakin meningkat karena mudah diakses, murah, dan bersifat pribadi. Penelitian tentang kemanfaatan internet terhadap kehidupan manusia khususnya remaja selama ini masih menjadi perdebatan. Hasil studi pendahuluan di Kabupaten Ponorogo (Ernawati, dkk , 20l4) bahwa 90 persen remaja pernah mengenal dan menggunakan internet, baik dengan memanfaatkan warnet, melalui handphone maupun melalui computer pribadi. Alasan remaja mencari artikel tersebut karena ada penugasan dari sekolah (mata pelajaran Biologi dengan Bab reproduksi) sekitar 56 persen, menambah wawasan tentang kesehatan reproduksi remaja sehingga bisa menjaga kesehatan reproduksi. Aspek kesehatan reproduksi remaja yang sering diakses adalah aspek menstruasi (74\%), perubahan fisik dan psikologis pada remaja (35\%), penyakit menular seksual termasuk HIVIAIDS (56\%) serta nutrisi pada remaja (67\%).

Penelitian Setyawan dan Susanto (2017) menggunakan media audio visual berbasis android sebagai penyampai informasi pada anak dalam meningkatkan kemampuan berbahasa. Media website banyak digunakan oleh remaja sejak internet menjangkau rumah dan sekolah, sehingga waktu yang digunakan remaja untuk mengakses internet pun semakin meningkat karena mudah diakses, murah, dan bersifat pribadi. Penelitian Ernawati, dkk (2014) tentang Penggunaan Sistem Informasi Berbasis Website pada Remaja menunjukkan bahwa rata-rata frekuensi akses situs dan durasi untuk informasi tentang kesehatan reproduksi remaja adalah I,36 kali seminggu dan I,65 jam. Kelemahan dalam penelitian ini tidak dilakukan pengamatan terhadap tentang penggunaannya oleh remaja putri, hal ini dikarenakan keterbatasan biaya dan waktu penelitian.

\section{KESIMPULAN}

Jadi dapat kita simpulkan bahwa hasil penelitian ini berdasar hasil analisis didapatkan p-value sebesar 0.000 $(p<0.05)$ yang menunjukkan intervensi penyuluhan video meningkatkan pengetahun remaja tentang anemia secara signifikan.

\section{UCAPAN TERIMA KASIH}

Penulis mengucapkan terima kasih kepada atas dana Risbinakes dan dukungan dari Direktur Poltekkes Kemenkes Palangka Raya, Kepala Pusat Penelitian dan Pengabmas beserta staf, tim reviewer, Pihak SMK YP SEI yang telah mengijinkan pelaksanaan penelitian serta partisipasi dari responden penelitian, enumerator dan seluruh pihak yang telah membantu sehingga proses penelitian ini dapat terlaksana.

\section{REFERENSI}

I. Kemenkes RI (20I8) Data dan Informasi Profil Kesehatan Indonesia 2017. Jakarta : Kemenkes RI

2. Kemenkes RI (20II) Modul Pelatihan Pelayanan Kesehatan Peduli Remaja (PKPR). Jakarta : Kemenkes RI

3. Kemenkes RI (2017) Data dan Informasi Profil Kesehatan Indonesia 2016. Jakarta : Kemenkes RI

4. Litbangkes Kemenkes RI., (2018) Riset Kesehatan Dasar 2018. Jakarta : Kemenkes RI

5. WHO, (2014) Global Nutrition targets 2025: Anemia Policy Brief. Geneva : World Health Organization

6. Departement of Nutrition For Health and Development WHO., (20II) Haemoglobin concentrations for the diagnosis of anaemia and assessment of severity. Geneva: WHO

7. Pusdatin Kemenkes RI (2014) Infodatin Situasi Kesehatan Reproduksi Remaja . Jakarta : Kemenkes RI 
8. Badan Pusat Statistik (20/3) Survey Demografi dan Kesehatan Indonesia 2012. Kesehatan Reproduksi Remaja. Jakarta : BPS.

9. Mularsih S., (2017) Hubungan Pengetahuan Remaja Putri Tentang Anemia Dengan Perilaku Pencegahan Anemia Pada Saat Menstruasi di SMK Nusa Bhakti Kota Semarang. Jurnal Kebidanan. 6(2) 80-85

10. Juliantara (2009) Media Audiovisual. Jakarta : EGC

II. Sadiman A., (2009) Media Pendidikan. Jakarta : PT. Raja Grafindo Persada

12. Suyatno (20II) Metodologi dan Aplikasi Penelitian Keperawatan. Bandar Lamung : Mulia Medika

13. Haryoko S.L., (2009) Efektifitas Pemanfaatan Media Audiovisual Sebagai Alternatif Optimalisasi Model Pembelajaran. Jurnal Edukasi. Vol. 5 o.I Maret 2009

14. Notoamodjo S., (2010) Ilmu Perilaku Kesehatan. Jakarta : Penerbit Rineka Cipta

15. Yusuf N., (2014) Pengaruh Pendidikan Kesehatan Tentang Penanganan Kejang Demam Menggunakan Media Audivisual terhadap Peningkatan Pengetahuan dan Sikap lbu dengan Anak Kejang Demam. Jurnal Stikes Kesuma Husada Surakarta. Vol.I No.2 Sept 2014

16. Dari (20I4) Pengaruh Pendidikan Kesehatan Senam Kaki Melalui Media Audio Visual Terhadap Pengeahuan Pelaksanaan Senam kaki Pada Pasie Diaebetes Melitus Tipe 2. JOM PSIK . Vol I No. 2 Okt 2014

17. Jusmiyanti , Misrawati, Jumaini ., (2013) Efektifitas Pendidikan Kesehatan Menggunakan Media Audiovisual terhadap Peningkatan Pengetahuan dan Kemampuan Ibu Merawat Bayi Baru Lahir. Skripsi

18. Santi S.M., Sabrian F., Karim D., (2014) Efektifitas Pendidikan Kesehatan Menggunakan Audiovisual Terhadap Perilaku Pencegahan Filariasis . JOM PSIK. Vo. I No. 2 Okt 2014

19. Arsyad (201I) Media Pembelajaran . Jakarta : PT. Raja Grafindo Persada
20. Puspitaningrum W., Agushybana F., Mawarni A., Nugroho J., (2017) Pengaruh media booklet terhadap pengetahuan dan sikap remaja putri terkait kebersihan dalam menstruasi di Pondok Pesantren Al-Ishlah Demak Triwulan II tahun 2017. Jurnal Kesehatan Masyarakat (e-journal). 5(4) 27428I

2I. Ernawati H., Hapsari E.D., (2014) Hubungan Antara Penggunaan Sistem Informasi Berbasis Website Dengan Pengetahuan Kesehatan Reproduksi Remaja di Kabupaten Ponorogo . Yogyakarta : Fakultas Kesehatan Masyarakat UGM

22. Setyawan., Susanto, (2017) Penggunaan Media Game Edukasi Berbasis Android Untuk Meningkatkan Kemampuan Berbahasa Anak Usia Dini . Jurnal Pendidikan Anak Usia Dini. Vol 3 No. 2 